\title{
First Report of Fusarium oxysporum f. sp. lycopersici Race 3 on Tomato in Brazil
}

\author{
Ailton Reis ${ }^{1}$, Hélcio Costa ${ }^{2}$, Leonardo S. Boiteux ${ }^{1 *} \&$ Carlos A. Lopes ${ }^{1 *}$ \\ 'Embrapa Hortaliças, Cx. Postal 218, CEP 70359-970, Brasília, DF, Brazil, e-mail: ailton @ cnph.embrapa.br; 2INCAPER/ \\ CRDR, CEP 29375-000, Venda Nova do Imigrante, ES, Brazil
}

(Aceito para publicação em 13/05/2005)

Corresponding author: Ailton Reis

REIS, A., COSTA, H., BOITEUX, L.S. \& LOPES C.A. First report of Fusarium oxysporum f. sp. lycopersici race 3 on tomato in Brazil. Fitopatologia Brasileira 30:426-428. 2005.

\begin{abstract}
Fusarium wilt, caused by three races of Fusarium oxysporum f. sp. lycopersici, is one of the most important diseases of tomato (Lycopersicon esculentum). Races 1 and 2 are distributed worldwide whereas race 3 has a more limited geographic distribution with no report thus far in Brazil. Seven F. oxysporum isolates were obtained from wilted tomato plants of race 1 and 2-resistant hybrids 'Carmen' and 'Alambra' in Venda Nova do Imigrante (State of Espírito Santo), Brazil. Virulence assays were performed using a set of the race differential cultivars: 'Ponderosa' (susceptible to all races), 'IPA-5' (resistant to race 1), 'Floradade' (resistant to races 1 and 2) and 'BHRS-2,3' (resistant to race 3). All isolates were highly virulent to 'Ponderosa', 'IPA-5' and 'Floradade' and were able to infect only a few plants of 'BHRS2,3'. An additional virulence test was conducted including the same set of cultivars plus Lycopersicon pennellii 'LA 716'. Identical results were obtained with L. pennellii displaying an extreme (immune-like) resistant response. These results indicated that all seven isolates could be classified as F. oxysporum f. sp. lycopersici race 3. This new Fusarium wilt might became an economically important disease since race 3-resistant cultivars adapted to Brazil are not yet available.
\end{abstract}

Additional keywords: Fusarium wilt, Lycopersicon, pathogen variability.

\section{RESUMO}

Primeiro registro da raça 3 de Fusarium oxysporum f. sp. lycopersici em tomateiro no Brasil

A murcha-de-fusário, causada por Fusarium oxysporum f. sp. lycopersici, é uma das doenças do tomateiro (Lycopersicon esculentum) de maior importância e mais amplamente distribuída no mundo. Até agora, foram identificadas três raças do patógeno, sendo as raças 1 e 2 disseminadas por todas as principais regiões produtoras do mundo. A raça 3 apresenta uma distribuição geográfica mais limitada e ainda não foi registrada no Brasil. Este trabalho teve os objetivos de determinar a raça de isolados de F. oxysporum f. sp. lycopersici, provenientes do Espírito Santo. Sete isolados de $F$. oxysporum foram obtidos de plantas murchas de tomate provenientes do município de Venda Nova do Imigrante-ES. Três isolados foram obtidas de plantas do híbrido 'Carmen' e quatro do híbrido 'Alambra', ambos considerados resistente às raças 1 e 2. O teste de virulência foi feito sobre um conjunto de cultivares diferenciadoras: 'Ponderosa' (suscetível a todas as raças), 'IPA-5' (resistente à raça 1), 'Floradade' (resistente às raças 1 e 2) e 'BHRS-2,3' (resistente à raça 3). Todos os isolados foram altamente virulentos às cultivares 'Ponderosa', 'IPA-5' e 'Floradade' e ainda infetaram algumas plantas da cultivar BHRS-2,3. O teste de virulência foi repetido com as mesmas cultivares, mas desta vez foi incluído o acesso 'LA 716' da espécie selvagem $L$. pennellii. Foram obtidos resultados idênticos com as cultivares, enquanto $L$. pennellii apresentou uma reação do tipo imunidade. Estes resultados indicam que os sete isolados avaliados pertencem à raça 3 de F. oxysporum f. sp. lycopersici. Esta doença pode se tornar importante no Brasil, devido ao fato que cultivares adaptadas e com resistência à raça 3 ainda não estão amplamente disponíveis.

Palavras-chave adicionais: murcha-de-fusário, Lycopersicon, variabilidade patogênica.

Fusarium wilt caused by Fusarium oxysporum Schlechtend: Fr. f. sp. lycopersici (Sacc.) W.C. Snyder \& H.N. Hansen is one of the most economically important and widespread diseases of the cultivated tomato (Lycopersicon esculentum Mill.). The virulence profile of $F$. oxysporum $\mathrm{f}$. sp. lycopersici isolates affecting tomatoes has been grouped into three races according to their ability to infect a set of differential cultivars carrying distinct resistance loci. Three

*Bolsistas CNPq.
Fusarium wilt resistance loci has been genetically characterized in Lycopersicon species. The locus $I$, from $L$. pimpinellifolium (Just) Mill. 'PI 79532' (Bohn \& Tucker, 1940), controls resistance to race 1 . Isolates capable of infecting cultivars with the locus $I$ were shortly after identified (Alexander \& Tucker, 1945) and a new disease resistance locus (I-2) was characterized in the accession 'PI 126915', which is a natural hybrid between $L$. esculentum and $L$. pimpinellifolium (Alexander \& Hoover, 1955). A third race able to infect cultivars carrying both $I$ and $I-2$ loci was 
reported first in Australia (Grattidge \& O'Brien, 1982) and a new resistance locus (named $I$-3) was identified in the wild species L. pennellii (Corr.) D'Arcy. Races 1 and 2 are distributed throughout the world whereas race 3 has a more limited geographic distribution. In Brazil, Fusarium wilt has been reported since the late 1930's in the State of São Paulo (Arruda, 1941). So far only races 1 and 2 are present occurring in virtually all producing areas of the country. More recently, isolates were obtained from distinct wilted plants of the $\mathrm{F}_{1}$ hybrids 'Carmen' and 'Alambra' in some production fields in Venda Nova do Imigrante, in Espirito Santo, Brazil. The initial interest in these isolates was due to the fact that 'Carmen' and 'Alambra' are both reported as being resistant to race 1 and 2 (genes $I$ and $I-2$ ). In this work we present the first formal report of $F$. oxysporum f. sp. lycopersici race 3 in Brazil.

Three isolates of this fungus (CNPH-89, CNPH-89a e CNPH-90) were obtained from distinct wilted plants of the $F_{1}$ hybrid 'Carmen' in a commercial field in Venda Nova do Imigrante, Espirito Santo, Brazil. Four additional isolates were obtained from wilted plants of the $\mathrm{F}_{1}$ hybrid 'Alambra' in the same county but on different farms (CNPH-91, CNPH94, CNPH-95 and CNPH-96). Fungus identification was done by observing and measuring the colonies, mycelia and conidia of the isolates (Booth, 1977; Summerell et al., 2003). The following race differential tomato cultivars were employed: 'Ponderosa' (susceptible to all races), 'IPA-5' (resistant to race 1 , due to the presence of the locus $I$ ), 'Floradade' (resistant to races 1 and 2, due to the presence of the loci $I$ and $I-2$ ) and 'BHRS-2,3' (resistant to the three races, probably due to the presence of the locus I-3). The genotypes were sown in Styrofoam trays with 128 cells, filled with sterile substrate. When the plants had the first two pairs of true leaves fully open (about 15 days after planting), they were removed from the cells with a gentle jet of water to preserve root integrity. The apical sector of the root system (about 2 $\mathrm{cm}$ ) was removed with a pair of scissors and then dipped for $1 \mathrm{~min}$ in a spore suspension of each race 3 isolate adjusted to approximately $10^{7}$ conidia/ml. Conidia were produced in Potato Dextrose Broth under standard conditions (Santos, 1999). As control, this set of differential accessions was also inoculated with race 1 and race 2 isolates. A group of plants from all differential cultivars were mock-inoculated with water. After inoculation, the plantlets were transplanted to $1.0 \mathrm{~kg}$ plastic pots, with sterile soil and maintained in the same greenhouse. The experimental plots were made of three pots with three plants each, replicated three times in a randomized block design. Disease was assessed 21 days after inoculation using an ordinal scale ( 1 to 5) where: $1=$ plant free of symptoms; 2 = plant without wilt symptoms but presenting conspicuous vascular browning; $3=$ plants showing vascular browning symptoms and wilt symptoms but without leaf yellowing; $4=$ severe wilting associated with the presence of foliar necrosis and chlorosis; $5=$ dead plant (Santos, 1999). A second experiment was conducted with the same set of cultivars but including this time $L$. pennellii
('LA 716'). Identical inoculation and evaluation procedures were done in this second assay but only the isolates that displayed more aggressiveness in the first assay as well as the new isolates obtained from 'Alambra' were employed.

All tomato F. oxysporum f. sp. lycopersici isolates rendered colonies with conidia and mycelia with morphological characteristics typical of $F$. oxysporum (Booth, 1977; Summerell et al., 2003). All seven isolates from Espírito Santo were virulent on 'Ponderosa', 'IPA-5' and 'Floradade'. These results were the first strong indication that these isolates could be assigned to a race distinct from either race 1 or 2 . These isolates were also able to induce wilting symptoms on some plants of the cultivar 'BHRS2,3'. This cultivar is derived from the interspecific cross $[L$. esculentum 'Contender' $\mathrm{x}$ L. pennellii 'PI 414773'] and it was found to be resistant to isolates of $F$. oxysporum $\mathrm{f}$. sp. lycopersici race 3 from Australia (McGrath, 1988). These initial results suggested either a slight pathogenic variability between Australian and Brazilian race 3 isolates or some segregation in the inbred line used in our assays. To clarify this situation, a second assay was conducted with this same set of cultivars but including the accession $L$. pennellii 'LA 716 ' (original source of the locus $I-3$ ). The results were similar to that observed in the first assay to the cultivars with $L$. pennellii 'LA 716' being immune to all isolates tested (Table 1). Therefore, the Brazilian isolates obtained from the hybrids 'Carmen' and 'Alambra' could be classified as F. oxysporum f. sp. lycopersici race 3. So far this race has a more limited geographic distribution being reported in Australia (Grattidge \& O'Brien, 1982); the United States (Jones \& Woltz, 1981; Volin \& Jones, 1982; Chellemi \& Dankers, 1992), New Zealand, United Kingdon (Urben, 1994) and Mexico (Valenzuela-Ureta et al., 1996).

The possible occurrence of race 3 in the State of São Paulo was reported by Tokeshi et al. (1966) as they found one isolate capable of infecting the cultivar 'Cast-M-wd', reported to be resistant to race 2 . However, this isolate was later reclassified as being race 2 because the cultivar 'CastM-wd' is not an adequate $F$. oxysporum f. sp. lycopersici race differential. This cultivar was found to be only partially resistant to race 2 even though not having the $I-2$ gene. Later, the cultivar 'Walter' (with the gene I-2) was found to be resistant to this putative race 3 isolate indicating an erroneous race classification (Noguez \& Tokeshi, 1974). Due to this initial misclassification there are some international reports indicating the presence of race 3 in Brazil (Jones \& Woltz, 1981). However, the work reported here is the first formal report of race 3 in Brazil, extending the geographical range of this pathogen. It is well known that $F$. oxysporum $\mathrm{f}$. sp. lycopersici can be introduced into new growing areas via contaminated seeds (Jones \& Woltz, 1981). The occurrence of race 3 in geographically isolated tomato-growing areas in Brazil could be the result of either pathogen introduction via contaminated seeds or the occurrence of an autochthonous race 3 isolate. In fact, recent results indicate that new race 3 isolates could have originated from genetic changes in the 
A. Reis et al.

Table 1 - Reaction of race differential accessions to Brazilian Fusarium oxysporum f. sp. lycopersici race 3 isolates

\begin{tabular}{|c|c|c|c|c|c|c|c|c|c|}
\hline \multirow{2}{*}{$\begin{array}{l}\text { Race } \\
\text { differential } \\
\text { accession }\end{array}$} & \multicolumn{9}{|c|}{ Isolates of Fusarium axysporum f. sp. lycopersici } \\
\hline & $\begin{array}{c}\text { CNPH } \\
89 \\
\end{array}$ & $\begin{array}{c}\text { CNPH } \\
89 a\end{array}$ & $\begin{array}{c}\text { CNPH } \\
90\end{array}$ & $\begin{array}{c}\text { CNPH } \\
91\end{array}$ & $\begin{array}{c}\text { CNPH } \\
94\end{array}$ & $\begin{array}{c}\text { CNPH } \\
95 \\
\end{array}$ & $\begin{array}{c}\text { CHPH } \\
96 \\
\end{array}$ & $\begin{array}{c}\text { CNPH } \\
23^{*}\end{array}$ & $\begin{array}{c}\text { CNPH } \\
27^{*}\end{array}$ \\
\hline Ponderosa & $4,14^{* *}$ & 4,15 & 4,63 & 4,70 & 4,32 & 4,41 & 4,60 & 4,80 & 3,76 \\
\hline IPA -5 & 4,50 & 4,22 & 4,75 & 4,50 & 4,57 & 4,71 & 4,40 & 4,53 & 1,00 \\
\hline Floradade & 4,36 & 4.08 & 4,61 & 3,40 & 4,29 & 4,43 & 3,90 & 1,00 & 1,00 \\
\hline BHRS -2,3 & 1,43 & 1,52 & 1,73 & 1,30 & 1,86 & 1,71 & 1,70 & 1,00 & 1,00 \\
\hline LA -716 & $\mathrm{NE}^{* * *}$ & $\mathrm{NE}$ & 1,00 & 1,00 & 1,00 & 1,00 & 1,00 & 1,00 & 1,00 \\
\hline $\begin{array}{l}\text { Race } \\
\text { classification }\end{array}$ & 3 & 3 & 3 & 3 & 3 & 3 & 3 & 2 & 1 \\
\hline
\end{tabular}

"Used as controls

**Average of 15 plants. Plants were evaluated using an ordinal scale ranging from $1=$ no symptoms to $5=$ dead plants.

${ }^{* * *} \mathrm{NE}=$ not evaluated.

local populations of native $F$. oxysporum f. sp. lycopersici isolates (Cai et al., 2003). Additional studies employing molecular fingerprinting systems and/or vegetative compatibility groups with a world-wide collection of $F$. oxysporum f. sp. lycopersici isolates could provide some indication of whether this pathogen is endemic to Venda Nova do Imigrante or if it was introduced and, if so, from which geographical area.

This new Fusarium wilt might became an economically important disease since race 3-resistant cultivars adapted to Brazilian conditions are not yet available. In addition, screening trials searching for new sources of resistance seems to be necessary since the genetic plasticity associated with selective pressures due to the use of race 3 resistant cultivars might cause the establishment of new pathogenic races of this fungus. These screening trials are already under way in Embrapa Hortaliças and new resistance sources have been found (Reis et al, 2004).

\section{LITERATURE CITED}

ALEXANDER, L.J. \& HOOVER, M.M. Disease resistance in wild species of tomato. Ohio Agricultural Experimental Station Research Bulletin 752, 1955.

ALEXANDER, L.J. \& TUCKER, C.M. Physiological specialization in the tomato wilt fungus Fusarium oxysporum f. sp. lycopersici. Journal of Agricultural Research 70:303-313. 1945.

ARRUDA, S.C. Murcha de Fusarium do tomateiro. Biológico 7:199200. 1941.

BOHN, G.W. \& TUCKER C.M. Studies on Fusarium wilt of the tomato. I. Immunity in Lycopersicon pimpinellifolium Mill. and its inheritance in hybrids. Missouri Agricultural Experimental Station Research Bulletin 311. 1940.

BOOTH, C. Fusarium. Laboratory guide to the identification of the major species. CMI. Kew, England. 1977.

CAI, G., ROSEWICH GALE, L., SCHNEIDER, R.W., KISTLER, H.C., DAVIS, R.M., ELIAS, K.S. \& MIYAO, E.M. Origin of race 3 of Fusarium oxysporum $\mathrm{f}$. sp. lycopersici at a single site in California.
Phytopathology 93:1014-1022. 2003.

CHELLEMI, D.O. \& DANKERS, H.A. First report of Fusarium oxysporum f. sp. lycopersici race 3 on tomatoes in Northwest Florida and Georgia. Plant Disease 76:861. 1992.

GRATTIDGE, R. \& O’BRIEN, R.G. Occurrence of a third race of Fusarium wilt of tomatoes in Queensland. Plant Disease 66:165-166. 1982.

JONES, J.P. \& WOLTZ, S.S. Fusarium-incited diseases of tomato and potato and their control. In: Nelson, P.E., Tousson, T.A. \& Cook, R.J. (Eds.). Fusarium: Diseases, Biology, and Taxonomy. Pennsylvania State University Press, 1981. pp.157-168.

McGRATH, D.J. BHRS 2-3 Fusarium wilt resistant tomato. HortScience 23:1093-1094. 1988.

NOGUEZ, M.A. \& TOKESHI, H. Revisão da classificação da raça 3 de Fusarium oxysporum f. sp. lycopersici). Anais da Escola Superior de Agricultura "Luiz de Queiroz" 31:419-430. 1974.

REIS, A., GIORDANO, L.B., LOPES, C.A. \& BOITEUX, L.S. Novel sources of multiple resistance to three races of Fusarium oxysporum $\mathrm{f}$. sp. lycopersici in Lycopersicon germplasm. Crop Breeding and Applied Biotechnology 4:495-502. 2004.

SANTOS, J.R.M. Protocolo de tecnologia: Seleção para resistência a doenças em Hortaliças. N. 3. Tomateiro/Murcha-de-fusário. Embrapa Hortaliças, Comunicado Técnico 11. 1999.

SUMMERELL, B.A., SALLEH, B. \& LESLIE, J.F. A utilitarian approach to Fusarium identification. Plant Disease 87:117-128. 2003.

TOKESHI, H., GALLI, F. \& KUROZAWA, C. Nova raça de Fusarium do tomateiro em São Paulo. Anais da Escola Superior de Agricultura "Luiz de Queiroz" 23:217-227. 1966.

URBEN, A.F. Molecular and genetic structure of populations of Fusarium oxysporum (Schlechtend Ex Fries) f. sp. lycopersici (Sacc) Snyder and Hansen and f. sp. radicis lycopersici Jarvis and Shoemaker (PhD Thesis). University of Birmingham, Birmingham 1994.

VALENZUELA-URETA, J.G., LAWN, D.A., HEISEY, R.F. \& ZAMUDIONALOA, V. First report of Fusarium wilt race 3, caused by Fusarium oxysporum f. sp. lycopersici, of tomato in Mexico. Plant Disease 80:105. 1996. (Note)

VOLIN, R.B. \& JONES, J.P. A new race of Fusarium wilt of tomato in Florida and sources of resistance. Proceedings of Florida State Horticultural Society 95:268-270.1982. 